\title{
Toward Technology-Sensitive Catching-Up Policies: Insights from Renewable Energy
} in China

Binz, Christian; Gosens, Jorrit; Hansen, Teis; Hansen, Ulrich Elmer

Published in:

World Development

Link to article, DOI:

10.1016/j.worlddev.2017.03.027

Publication date:

2017

Document Version

Peer reviewed version

Link back to DTU Orbit

Citation (APA):

Binz, C., Gosens, J., Hansen, T., \& Hansen, U. E. (2017). Toward Technology-Sensitive Catching-Up Policies: Insights from Renewable Energy in China. World Development, 96, 418-437.

https://doi.org/10.1016/j.worlddev.2017.03.027

\section{General rights}

Copyright and moral rights for the publications made accessible in the public portal are retained by the authors and/or other copyright owners and it is a condition of accessing publications that users recognise and abide by the legal requirements associated with these rights.

- Users may download and print one copy of any publication from the public portal for the purpose of private study or research.

- You may not further distribute the material or use it for any profit-making activity or commercial gain

- You may freely distribute the URL identifying the publication in the public portal 


\title{
Toward Technology-Sensitive Catching-Up Policies: Insights from Renewable Energy in China
}

\author{
CHRISTIAN BINZ ${ }^{\mathrm{a}, \mathrm{e}, 1}$, JORRIT GOSENS $^{\mathrm{b}, 1}$, TEIS HANSEN ${ }^{\mathrm{a}, \mathrm{c}, 1}$ and ULRICH ELMER HANSEN $^{\mathrm{d}, 1, *}$ \\ ${ }^{\text {a }}$ Lund University, Sweden \\ ${ }^{\mathrm{b}}$ Chalmers University of Technology, Göteborg, Sweden \\ ${ }^{\mathrm{c}}$ Nordic Institute for Studies in Innovation, Research and Education (NIFU), Oslo, Norway \\ ${ }^{\mathrm{d}}$ Technical University of Denmark, Kobenhavn, Denmark \\ ${ }^{\mathrm{e}}$ Eawag - Swiss Federal Institute of Aquatic Science and Technology, Dübendorf, Switzerland
}

\begin{abstract}
Summary. - The voluminous literature on industrial catching-up in Southeast Asian countries has regularly argued that successful catching-up largely depended on a committed state, which orchestrated industry development with a relatively uniform set of policies, including R\&D support, subsidies, trade restrictions, and local content requirements. In contrast, recent contributions from the technology lifecycle literature have argued that policies should be tailored to differing technological characteristics in industries for massproduced standardized goods, complex engineered products, and - as we argue - complex product systems (CoPS). In this paper, we extend this argument by introducing a set of separate policy mixes for each industry type, which appears most capable of providing the key resources required for catching-up: knowledge, market access, financial investment and technology legitimacy. This framework is used to analyze catching-up patterns in China's wind, solar PV, and biomass power plant industries, drawing mainly on policy documents and 106 interviews with key industry actors.

We find that traditional top-down catching-up policies played a decisive role in the development of China's wind industry, but were of limited importance in the early solar PV industry, and resulted only in a limited period of rapid growth in the biomass power plant industry. The relative progress achieved in these three industries is not related to top-down policy guidance alone, but also to private sector initiative, international interdependencies, and flexibility in adapting policy mixes to each industry's technological characteristics. These results suggest that policy makers in newly industrializing countries (NICs) should avoid drafting generic sector plans, but should tailor plans to individual industries, and respond to changing policy support needs as technological capacities and global competitiveness develop.

(C) 2017 Elsevier Ltd. All rights reserved.
\end{abstract}

Key words - catching up, technology characteristics, policy mix, renewable energy, China

\section{INTRODUCTION}

The literature on industrial catching up and infant industries has provided a comprehensive account of how the remarkable industrial and economic development in (East-) Asian countries has taken place. Empirical evidence often showed that the state played a key role in orchestrating catching-up using various policy instruments, including subsidies, trade restrictions, R\&D support, and local content requirements (Rock, Murphy, Rasiah, van Seters, \& Managi, 2009). Scholars have argued that state interventions should couple industry protection to competition, be based on long-term strategic goals and have a high degree of coherence-i.e., combine centralized decision-making structure within the state with a high degree of public-private cooperation (Wade, 1988). 'Successful' policy interventions were in most cases shown to depend on top-down policy making, requiring a committed, interventionist state apparatus (labeled the 'Asian development State') closely involved in industry development (Angel \& Rock, 2009; Carlsson \& Stankiewicz, 1991; Kim, 1997).

This paper aims at differentiating such stylized policy recommendations in two main respects. First, we emphasize that catching-up dynamics may considerably differ between industries with varying technology characteristics. To this end we follow recent conceptual contributions from the technology lifecycle literature in distinguishing coarsely between the catching-up challenges for industries with mass-produced standardized goods (e.g., solar PV panels) versus complex engineered products (e.g., wind turbines) (Hansen, Klitkou, Borup, Scordato, \& Wessberg, 2017; Huenteler, Schmidt, Ossenbrink, \& Hoffmann, 2016; Schmidt \& Huenteler, 2016). We further add a third technology type, complex product systems (CoPS) (e.g., biomass power plants) (Hobday, 1998, 2000).

Second, we connect catching-up studies with the literature on innovation systems, to derive a set of policy mixes that seem most adapted to specific catching-up requirements of each industry type. The catching-up literature to date mostly emphasizes supply-side policy interventions which support latecomer firms in upgrading their knowledge-based technological capabilities (Morrison, Pietrobelli, \& Rabellotti, 2008). We broaden the focus to policy interventions that may influence the innovation process in other important dimensions related to market deployment, financial investment, and technology legitimacy (cf. Binz, Truffer, \& Coenen, 2016). An analytical framework is derived that allows scrutinizing how policy makers may provide latecomer firms with access to key system resources in all four dimensions,

\footnotetext{
* Christian Binz would like to thank the Swiss National Science Foundation (Early Postdoc. Mobility Grant P2BEP1_155474) for funding this project. Jorrit Gosens gratefully acknowledges financial support from The Swedish Research Council Formas (grant no. 2015294). The sponsors mentioned above did not have any involvement in research design or reporting. Final revision accepted: March 19, 2017.
} 
and how resource formation processes may differ between different industry types.

Our framework is illustrated with three renewable energy industries that correspond with the three industry types included in our framework; solar PV panels, wind turbines, and biomass power plants, each of which has seen strong development in China over the last decades. Based on a comparative analysis of public policy documents, secondary literature, and 106 expert interviews, we discuss the policy support biographies of each industry in detail. Our analysis identifies significant differences in the policy mixes that supported industry development. Top-down state intervention played the most instrumental role in the catching-up process for wind turbines, but were of lesser importance in the early development phases of the solar PV industry. State intervention in the biomass industry resulted in a limited period of rapid growth. China's relative success in developing these industries can accordingly not be attributed to strategic topdown governance alone, but is also reliant on different forms of private sector initiative, international interdependencies, and the flexibility of China's decision makers in adapting policy mixes over time, to the specific needs of industries with varying technology characteristics.

In the remainder we elaborate this argument as follows: we first review the catching-up literature and connect its views on policy intervention with recent insights from technology lifecycle and innovation system scholars. We then introduce a stylized typology of technology-specific catching-up policy mixes, which is empirically illustrated with examples from the Chinese renewable energy sector. The paper ends with a discussion of how our analytical framework and the Chinese catching-up experience in renewable energy may inform a research agenda and concrete policy recommendations for other latecomer countries.

\section{THEORY: CATCHING UP AND INDUSTRY FORMATION}

\section{(a) Catching-up policies - the conventional view}

Within economic history and the broader literature on industrialization strategies and economic development, much research has been conducted on the development and catching-up of infant industries in developing countries (Freeman, 1987; Lee \& Lim, 2001; Perez, 1985). Of particular interest have been the remarkable economic development of post-War Japan and the development of the newly industrializing countries (NIC) in East Asia, such as Hong Kong, Malaysia, Singapore, South Korea, and Taiwan, since the 1980s (Amsden, 1992; Hobday, 1995; Mathews \& Cho, 2007). Research in this field has focused on analyzing how the structural transformation of these economies could take place in a relatively short period of time, and derived generalizable lessons for industrial and economic development policies in other NICs. An extensive body of empirical studies have highlighted the crucial role of the state in promoting the development of young or emerging domestic industries in Asian NICs (Chang, Cheema, \& Mises, 2002; Lall, 1992; Page, 1994; World Bank, 1993). In general, authors have stressed the similarities of support models adopted across different countries, and "explicitly link[ed] state intervention and rapid economic development" (Chen \& Lees, 2016, p. 575). A series of conditions have been identified as conducive for achieving rapid and advanced levels of industry development (summarized from Chen \& Lees, 2016; Freeman, 1988; Kim, 1997; Kjaer, 2004; Wade, 1988, 1990):

- Policies were coherent and comprised mutually reinforcing sets of 'carrot and stick' incentives, for example performance based subsidies or sanctions (Chen \& Lees, 2016; Kjaer, 2004).

- Policy implementation involved close central coordination among different agencies and ministries in charge of different support instruments and functions, e.g., MITI in Japan (Freeman, 1988)

- The overall orchestration was performed by powerful governments that formulated strong long-term industrialization strategies that provided overall priorities and consistency (Freeman, 1988; Kim, 1997)

- The detailed implementation was undertaken by competent and well-remunerated bureaucracies that maintained close contacts with firms (Wade, 1988, 1990)

- High degree of co-operation between government bureaucrats and managers of private enterprise was established, involving governments pressing firms to form industry associations and co-operative bodies to coordinate public-private interaction (Cimoli, Dosi, \& Stiglitz, 2009; Yeung, 2016)

- Withdrawal of industry protection was managed in a gradual fashion. Close consultation and monitoring, together with the strictly conditional terms on which support was provided, were the main mechanisms to ensure that protection would be temporary (Wade, 1988).

China has increasingly become one of the focal countries in literature in recent years (Altenburg, Schmitz, \& Stamm, 2008; Appelbaum, Parker, \& Cao, 2011; Niosi \& Reid, 2007; Yu, Malerba, Adams, \& Zhang, 2016). Like the earlier NICs, China has a highly centralized state apparatus, and studies on the rapid catching-up of Chinese industries have often sought to draw parallels with the industry formation dynamics identified in the earlier NIC. Consequently, China's rapid economic growth has been argued to be largely attributable to strong state involvement in infant industries (cf. Lee, Cho, \& Jin, 2009; Liu, 2005; Malerba \& Nelson, 2011; Sun, 2015; Xiao, Tylecote, \& Liu, 2013). For example, Chen and Lees argue that China's remarkable progress in developing renewable energy industries are due to an "approach to governance [that] conforms to the developmental state model" (Chen \& Lees, 2016, p. 4). Among others, this included a role for the National Development and Reform Commission (NDRC) as the central agency orchestrating the government's vision, strong links between government agencies and the mostly state-owned power generation, distribution, and equipment manufacturing industries, numerous policy documents detailing the state's vision, and a set of incentives including feedin tariffs, and sanctions for power companies not attaining renewable portfolio targets (Chen \& Lees, 2016). Liu and Liang (2013) review 12 categories of clean energy technologies and similarly stress the importance of the national innovation strategy, pointing to central government agencies, a largely state run science system, and dominance of state-owned enterprises (SOE) in energy sectors. They conclude that "China's advance in clean energy technology is a result of long-term government research and development", and that, like in China, "active government involvement in innovation is common in the successful catch-up economies in East Asia" (Liu \& Liang, 2013, p. 496).

In this paper we will qualify the conventional view discussed above in two main respects. First, an all-too-direct extension of the developmental state model on recent catch-up experiences in NICs like China appears problematic (Shen, 2016). 


\section{دريافت فورى ـ ـ متن كامل مقاله}

\section{ISIArticles}

مرجع مقالات تخصصى ايران

ل امكان دانلود نسخه تمام متن مقالات انكليسى ل امكان دانلود نسخه ترجمه شده مقالات ل يذيرش سفارش ترجمه تخصصى $\checkmark$ ل امكان جستجو در آرشيو جامعى از صدها موضوع و هزاران مقاله ل امكان دانلود رايكان r صفحه اول هر مقاله

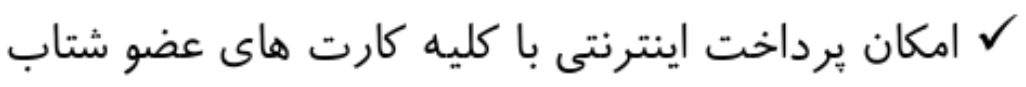
ل دانلود فورى مقاله پِ از برداخت آنلاين

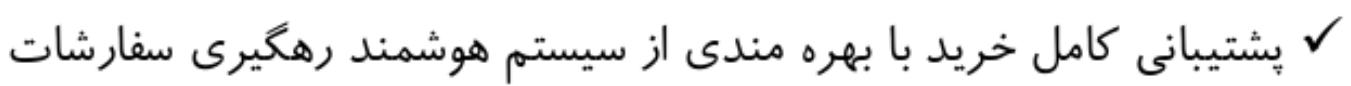

